University of Wollongong

Research Online

Faculty of Commerce - Papers (Archive)

Faculty of Business and Law

$1-1-2007$

\title{
Rebels without applause: time, politics and irony in action research
}

\author{
R J. Badham \\ Macquarie Graduate School of Management \\ Karin Garrety \\ University of Wollongong, karin@uow.edu.au
}

M. Zanko

University of Wollongong, mzanko@uow.edu.au

Follow this and additional works at: https://ro.uow.edu.au/commpapers

Part of the Business Commons, and the Social and Behavioral Sciences Commons

\section{Recommended Citation}

Badham, R J.; Garrety, Karin; and Zanko, M.: Rebels without applause: time, politics and irony in action research 2007.

https://ro.uow.edu.au/commpapers/451

Research Online is the open access institutional repository for the University of Wollongong. For further information contact the UOW Library: research-pubs@uow.edu.au 


\title{
Rebels without applause: time, politics and irony in action research
}

\begin{abstract}
Purpose of this paper: This paper seeks to raise for discussion and reflection some of the key dynamics of action research projects-in-practice. It focuses in particular on how action researchers broker academic and client interests, and how this brokering shifts over time. Design/methodology/approach: The paper is based on participant observation, drawing on the reflective and processual accounts of action researchers involved in a collaborative academic-industry-government project. Findings: The paper argues that the scope of action research projects to effectively address the needs of both audiences is compromised by managerialism in universities and organizations. However, the emergent and chaotic nature of action research provides opportunities for researchers to overcome some of these limitations. Research limitations/implications (if applicable): The paper provides a model and case analysis to support critical reflection amongst action researchers. Practical implications: If the argument of the paper is accepted, then action researchers are required to pay greater attention to the dangers of managerialism in universities, and explore how such dangers can be overcome. What is original / value of paper? The originality of the paper lies in its self-critical sociological reflexivity. Its value depends on whether or not this is found to be valuable by action researchers.
\end{abstract}

\section{Keywords}

Action Research, Processual, Politics, Managerialism, Foolishness, Irony.

\section{Disciplines}

Business | Social and Behavioral Sciences

\section{Publication Details}

This article was originally published as Badham, RJ, Garrety, K and Zanko, M, Rebels without applause: time, politics and irony in action research, Management Research News, 30(5), 2007, $324-334$. 
Rebels without Applause:

Time, Politics and Irony in Action Research

Richard Badham, Karin Garrety and Michael Zanko

Contact Author (First Author) Details

Macquarie Graduate School of Management,

Macquarie University, Sydney NSW 2091

Email: richard.badham@mgsm.edu.au

Abstract

\begin{tabular}{|l|l|}
\hline Purpose of this paper: & $\begin{array}{l}\text { This paper seeks to raise for discussion } \\
\text { and reflection some of the key dynamics } \\
\text { of action research projects-in-practice. It } \\
\text { focuses in particular on how action } \\
\text { researchers broker academic and client } \\
\text { interests, and how this brokering shifts } \\
\text { over time. }\end{array}$ \\
\hline Design/methodology/approach: & $\begin{array}{l}\text { The paper is based on participant } \\
\text { observation, drawing on the reflective } \\
\text { and processual accounts of action } \\
\text { researchers involved in a collaborative } \\
\text { academic-industry-government project. }\end{array}$ \\
\hline Findings: & $\begin{array}{l}\text { The paper argues that the scope of action } \\
\text { research projects to effectively address } \\
\text { the needs of both audiences is } \\
\text { compromised by managerialism in } \\
\text { universities and organizations. However, } \\
\text { the emergent and chaotic nature of action } \\
\text { research provides opportunities for } \\
\text { researchers to overcome some of these } \\
\text { limitations. }\end{array}$ \\
\hline Research limitations/implications (if applicable): & $\begin{array}{l}\text { The paper provides a model and case } \\
\text { analysis to support critical reflection } \\
\text { amongst action researchers. }\end{array}$ \\
\hline Practical implications: & $\begin{array}{l}\text { If the argument of the paper is accepted, } \\
\text { then action researchers are required to } \\
\text { pay greater attention to the dangers of }\end{array}$ \\
\hline
\end{tabular}




\begin{tabular}{|l|l|}
\hline & $\begin{array}{l}\text { managerialism in universities, and } \\
\text { explore how such dangers can be } \\
\text { overcome. }\end{array}$ \\
\hline What is original / value of paper? & $\begin{array}{l}\text { The originality of the paper lies in its } \\
\text { self-critical sociological reflexivity. Its } \\
\text { value depends on whether or not this is } \\
\text { found to be valuable by action } \\
\text { researchers. }\end{array}$ \\
\hline
\end{tabular}

Keywords Action Research. Processual, Politics. Managerialism. Foolishness. Irony.

\section{Introduction: A Tale of Two Projects?}

\subsection{Project 1}

Australia has an established history of participatory action research, exemplified in the work of Fred Emery, and widely promoted as part of a progressive push for workplace reform in the 1980s and 90s (Einjatten,1993; Mathews, 1994). The firstnamed author has been a participant (Dawson, 2003b) in this movement (Dunphy and Griffiths, 1998). In 1999 he and his colleagues obtained funding from the Australian Research Council (ARC) to continue this work in an 'Evaluation for Learning' (EFL) project that proposed an innovative evaluation of a long term organizational development (OD) program at a large Australian industrial company (Steelmaking Oz). The project was part of a major collaboration between the author's university and the company, administered through a joint Institute for Steel Processing and Products (ISPP). With the assistance of the Institute's combined industry/academic Technical Advisory Committee (TAC), the first author worked closely with the OD 
representative from Steelmaking $\mathrm{Oz}$ to create a project of strategic interest to both the company and the university. A substantial number of OD program participants were interviewed to obtain their 'stories' of change. These were disseminated in the corporation, and supplemented by a workshop with supervisors to improve their appreciative inquiry and storytelling abilities. In the final report to the ARC, the industry partner confirmed that 'the collection of stories on the program and the appreciative inquiry processes were of significant value and interest to the business.' The academics published their findings, which focused on the OD program as a form of identity regulation, in leading organization studies journals.

\subsection{Project 2}

The efficacy of many work humanization reforms in Australia and elsewhere (Badham and Naschold, 1994) has been questioned by many (Hampson, 1999). Collaboration between academic social scientists and industry has long been controversial, with critics condemning it as 'cow sociology' ('keep them happy, and milk them harder') or manipulative social engineering wrought by academic 'servants of power' (Badham and Selden, 1996; Baritz, 1960; Bell, 1947; Rose, 1999). In the contemporary context of managerialised universities and declining union strength, the push for 'relevant' social science research in industry, while often liberatory in its rhetoric, becomes, at best, suspicious.

The authors established a project to uncover and discuss some of the more manipulative elements of contemporary OD, and to work collaboratively with managers and employees to create a more democratic approach to change. There was 
initial enthusiasm from the OD manager, who wrote in support of the project application:

"This project... is not one that has been proposed for us by academics. It has been a truly joint development... The University has worked with us to define an approach to evaluation in a way that embodies the learning principles of the program itself."

However, once funding was approved, and researchers hired, the OD manager tightly restricted access to the plant, explicitly betraying the espoused 'learning principles' of the program (but, arguably, reflecting the actual learning applied!). As he wrote in a letter submitted to the university Ethics Committee:

"Permission is for collection .. and analysis by themes only. There is to be no validation or cross checking ... There is to be no engagement by the University of the (Steelmaking $\mathrm{Oz}$ ) political system with respect to the continuation of the Leadership Programme."

In the first formal meeting to set up the empirical project, the main consultant working with the OD manager laconically proclaimed that the purpose was for the academics "to be propagandists for a bunch of wanky consultants to help them make more money out of Steelmaking Oz.” Interview subjects were selected by the OD department, who also kept control over transcripts. The term 'evaluation' was banned from project discussions and reports. One of the hired researchers left before the end of his contract, and the research team was divided over whether or not to allow the 
project to continue in the light of the betrayal of the research principles and practices outlined in the original proposal.

\subsection{Triumph and Disaster?d}

Two projects - one a triumph and the other a disaster? Possibly...but they are alternative descriptions of the same project! The purpose of this little deceit is to illustrate the intertwining of two dimensions of action research, and to use a discussion of these dimensions in the case study to inform critical reflection on this type of research. The two dimensions are: firstly, the pressure on collaborators to produce managerial deliverables and collude in covering up any threats to those deliverables; and, secondly, the potential of informal, covert and messy research dynamics to promote critical action and reflection. At one level, the paper discusses both dimensions in an attempt to capture action researchers 'actual' 'theories in use' (rather than 'espoused theories') as a contribution to reflective learning (Argyris, 1982). At another level, accepting that measures of 'success' or 'failure' are socially constructed and contentious, the paper suggests that action researchers adopt a more ironic approach to recognizing and influencing how these labeling processes play themselves out.

To help inform what will be a cursory description of the project, the analysis will be structured in two ways. Firstly, as we have argued elsewhere, and as illustrated in Figure 1, the dynamics of action research involve attempts by researchers to serve both academic and industry audiences (Badham and Sense, 2006). [PUT FIGURE 1 HERE] While they may be guided by joint academic-industry concerns, processes of 
reflection, planning, action and observation are understood and evaluated differently by academic and industry audiences. The key 'bricoleuring' role of the action researcher is to 'spiral up' - to run a project that provides benefit to both audiences without 'spinning out' to become an industrial 'consultant' or a 'traditional' extractive academic researcher.

Secondly, the issues that the action researcher has to address in playing this bricoleuring role will vary depending on the stage of the project and the academic and industry client 'systems'. If we employ a 'social worlds' framework for exploring these issues, as we have done elsewhere (Garrety and Badham, 2000), academics and industrial managers can be understood as inhabiting different social worlds, that possess and lobby for alternative views of existing and desirable project trajectories. While the actual trajectories are often complex amalgams of plans, actions and outcomes, with fuzzy time-lines, a rough periodisation helps us focus on the issues that emerge at various times. In the early stages, the main issue is 'getting in' (Buchanan, 1988; Dumont 1991), that is, determining what kind of research should be undertaken, lobbying for resources and support, and initial sense-making among participants as they attempt to understand each other. This stage is usefully characterized in terms of the activities prior to what is frequently an 'obligatory passage point' - (Latour 1987, 141) the signing (or agreement upon) some kind of formal (or informal) contract to proceed with the main empirical or fieldwork stage (Wotherspoon, 2002). The second 'getting on' phase focuses on conducting the empirical research or fieldwork. Collaborators form a common understanding of each other and the project. Ideally, this stage culminates in the preparation of the agreed research 'deliverables'. During the final 'getting out' phase, deliverables, including 
academic articles, are drafted and disseminated. In an idealized view of research, these outcomes are meaningful for both the academic and industry collaborators.

Our purpose in exploring these dimensions, tensions and stages is to help inform a more open and reflective analysis of action research in practice. In so doing we seek to foster a more engagingly ironic view, avoiding both too strong an identification with its proclaimed democratic and epistemological goals or too critical a disidentification and dismissal of all such research as inherently corporatist-managerial.

\section{Managerialism, Collusion and Cover Up}

Before outlining the stages in the case study project, some institutional background is helpful. The ISPP was established in a university whose engineering department had already enjoyed several decades of collaboration with Steelmaking $\mathrm{Oz}$ in course development and research. The ISPP was set up to formalize and advance the strategic alliance between the organizations. Its mission was to carry out world class technological and management research on steel and establish a training program for managers to support Steelmaking Oz's expansion into the Asia-Pacific region. The expansion never eventuated, so the ISPP's focus remained on research.

The bias towards engineering made it difficult for the ISPP's Professor of Management (the first author) to establish projects that would gain the continued support of all interested parties. Although engineers in both organizations understood the role of management academics in training, they held a positivist view of management research as involving surveys and statistics. Human resource managers 
in Steelmaking $\mathrm{Oz}$ were also difficult to enroll as allies. They were not involved in the establishment of the ISPP and did not initially see much value in university research. They used their own consultants for OD initiatives

Another significant feature of the ISPP was that it required academics to fund their research through the Australian Research Council (ARC) grant scheme, mainly as applied 'Linkage' projects with combined government and industry funding. Successful applications provided funds, legitimacy and prestige, and a structure for formally identifying 'world class' research and obtaining industry 'buy in', as well as processes for monitoring industry satisfaction with the research. What this meant for academics navigating the spiral of action research was that all evaluations of academic and industry contributions were mediated through the ARC project structure. In terms of 'getting in', the key focus was on negotiating sufficient agreement to prepare and submit an ARC grant application. In regard to 'getting out', the main focus was on not only obtaining industry sign off and producing academic publications, but doing so in a manner that supported further collaboration and grants. The 'getting on' dimension was independently run by the direct industry-academic partners but progress was monitored by the ISPP's TAC. This context had a direct impact on research initiatives such as the 'Evaluation for Learning' project.

\section{$2.1 \quad$ Getting In}

The 'getting in' phase was dominated by the requirements of the grant application, as both academic and industry parties focused on creating a compelling narrative for the ARC. At this stage, the academics played a leading role in crafting the application 
and, in particular, identifying research questions and methodologies that would impress the ARC assessors. In terms of bricoleuring, this was a highly creative and sensitive phase. As the time span from initial grant writing to the commencement of data-gathering for such projects is nearly two years, obtaining a statement from the industry partner asserting the importance and urgency of the research problem is not easy! Somehow, the bricoleur had to establish relevance, provide value, and develop relationships prior to obtaining funds. (S)he also had to motivate the industry partner to participate in a tortuous bureaucratic application process. The crafting of the academic justification was equally challenging, as the 'problems' identified by industry clients as significant are often not so significant to academics, or need to be re-focused to make sense to funding bodies. As success depends on a 'lottery' of peer review, such projects have an aura of unreality about them for the 18 months from conception to approval or rejection by the ARC.

In the EFL Project, the HR manager on the TAC was encouraged by his technical peers to support the management stream of the ISPP, and so arranged a meeting between the first author and the OD manager at Steelmaking Oz. At this meeting, the OD manager expressed an interest in obtaining and circulating 'stories' about the OD program, which were consistent with his interest in promoting it. He also had a relatively sophisticated view of the importance of the non-rational dimensions of change, including the significance of storytelling that could be harnessed to the interests of the academics. However, neither the HR nor OD manager was particularly enthusiastic about collaboration. There were no established relationships, no major intellectual synergies, or political pressures supporting meaningful partnership. 
However, the project was significant for the TAC, since many members had attended the OD program and were interested in its evaluation. The project was also of major interest to the academics. The OD initiative, centered around off-site workshops and follow up activities, was highly controversial both inside and outside the company. Inside the company, with a highly politicized aura of status and secrecy surrounding the workshops (Badham et.al, 2003.), and a number of alleged suicide attempts following them, the project had both strong supporters and vehement critics. In academia, the identity deconstructive 'T-group' processes employed by the program were also controversial, on both moral-ethical and pragmatic-effectiveness grounds (Turnbull, 2001). In order, therefore, to integrate the interests of the OD manager, the TAC and the academics, the first author created an application that proposed the use of a novel social constructivist 'fourth generation' method of evaluation (Guba and Lincoln, 2005) to collect from developers, supporters and critics their stories about the program, and establish a collaborative and iterative process of participatory sense-making. The aim was to uncover differences of opinion and fact, and encourage a more open and inclusive dialogue for the program's further development. How this was managed politically was also an important part of the study. With the industry sign off, and ARC approval for funding, the initial signs were positive and the lack of strong urgency from the OD manager was initially useful for the project in that he was willing to wait for the outcome before beginning research. However, there was an ever-present potential, common in such projects, that the initial dominance of academia creates a 'spinning out' in the direction of a purely academic project rather than a genuine collaboration - a factor that showed up only too clearly as the project moved into the next phase. 


\subsection{Getting On}

At the beginning of this phase in such projects, considerable effort has been put into the application, and, when it is successful, the academics responsible are praised and rewarded. They are reluctant to consider stopping the project as they enter renegotiations with the industry client over details of the research activity and access. During the 'getting on' phase, these partners can wield considerable power, both through their control over industry resources and their authority to comment on progress and outcomes.

In the EFL Project, the OD manager tightly restricted access to interview subjects and excluded the term 'evaluation' from project discussions and reports. For him and his staff, the project was concerned with 'storytelling' rather than evaluation. It became apparent that, despite signing off, he neither understood nor cared for the 'fourth generation evaluation', was highly suspicious of independent academic research, and was very concerned to prevent negative portrayals of the OD program. Stories were only to be collected from people selected by the OD group, transcribed and fed back to these people for their approval, and then passed on to the OD group for dissemination - not an iterative process of dialogue among developers, supporters and critics. The OD group decided to place the stories on the company web site in the hope of stimulating more positive stories - not to allow participatory workshops to communicate and resolve differences. An initiative was also created to train supervisors in appreciative inquiry and 'positive' storytelling techniques - rather than 
support an iterative process of conflict identification, dialogue, research and resolution.

The OD manager, designated as the formal project partner by the ARC and the TAC, also had considerable influence due to other institutional factors. Because the ISPP was organized around the creation of a stream of funded ARC projects - strongly supported by senior university and company management - anything that disrupted a 'success' story being told about a project was controversial. For the academics to raise questions about the direct industry collaborators not only undermined their relationships with those partners, but revealed to the TAC that their project was hitting problems, and to the ISPP Board that their academic program was not fulfilling its strategic objectives. Thus, there were strong pressures to 'cover up' any deviations by collaborators. In addition, monitoring by the TAC combined with procedures mandated by the university Ethics Committee restricted opportunities to conduct informal 'research by walking around' (Dawson, 2003a). There is a substantial danger - exemplified in this case - of collaboration in the 'getting on' phase to become a limited form of consultancy rather than a theoretically informed and reflective action learning process.

\subsection{Getting Out}

At the conclusion of a funded project, the ARC requires formal assessments from the industry collaborator as well as evidence of academic output. If the track record necessary to support future grant applications is not to be endangered, a supportive statement from the industry partner is also desirable If further industry collaboration 
is sought, industry partners need to perceive value that goes beyond any formal statements. Academic output that is critical of the industry partner, or that veers from accounts that the industry partner wishes to have told is thus potentially threatening to academic careers.

In the EFL Project, the range of issues that could be addressed in publications was circumscribed by the limited access. Within these limitations, however, significant data were collected and analysis undertaken on the use of the Myers Briggs Type Indicator to influence identities in the company (Garrety et.al., 2003 Badham et.al, 2003, Garrety forthcoming). Academic drafts given to the industry partner for comment were returned with little response. Care was taken, however, in the wording of initial articles so as not to appear too critical of the program and its effects. Members of the OD department did not seek any further feedback from the academics regarding the MBTI or identity issues in the company.

In the final report to the $\mathrm{ARC}$, and in formal presentations and advice to the TAC and ISPP board, the project was presented and received as a success - with industry sign off and a significant number of completed and planned academic publications, and further grant applications to its credit. The conditions for systematic reflection within the university (at least beyond the direct academic team) did not exist, however, and critical dialogue between industry and academia was not encouraged or permitted. The interests of a university committed to enhancing competitive research funding and industry stakeholders concerned with maintaining an image of support for the local university represented an institutional 'mobilization of bias' (Zanko, Badham, Couchman and Schubert, forthcoming) that prevented private grievances between 
partners from being publicly aired (Badham, forthcoming). When the first author in a high level university-industry forum raised the possibility of concentrating on significant academic and industry outcomes rather than further grant success, he was openly (and in private) censured by the Vice Chancellor and warned by an industry collaborator to 'look at the deep structures of power...they can swat you like a fly.'

\section{Informal, Covert and Messy Research Dynamics}

As portrayed in Figure 1, action researchers inevitably juggle conflicting interests, and must bricoleur in the face of uncertainty. In Cohen and March's (1974) terms, their choice is not between 'rational' and 'irrational' action, but between different types of foolishness, and opting for what appears to be more 'sensible' i.e. judgements have to be made in the context of conflicting and uncertain goals, controversial and only partially understood means and so on. As part of a an attempt to negotiate their way around such conditions, by 'purposive muddling through' (Quinn, 1980), action researchers are required to balance 'rhetorics of administration' with 'rhetorics of realpolitik' (March and Olsen 1983) in the 'garbage can' (Cohen, March and Olsen, 1972) of inter-organizational collaborations. What might appear initially (or on reflection) as rational action informed by clear knowledge of structures and interests can collapse into less 'rational' endeavours drawing on subjective and contentious

opinions about contexts and realms of maneuver. Underneath a rubric of 
managerialism and collusion, the EFL Project revealed more of this subterranean nonrational world than is at first apparent.

Firstly, in the process of 'Getting In', the 'evaluation' versus 'storytelling' tension in the project definition was biased in the ARC application towards 'evaluation' - albeit with constructivist 'storytelling' elements. Although the application differed substantially from what the TAC initially perceived as 'evaluation', industry members supported an opportunity to explore controversial dimensions of the OD philosophy and methods. While the Vice Chancellor and the University research administration were not aware of or interested in a critical line of inquiry, a group of researchers in the Faculty of Commerce, supported by the Dean, took up the opportunity of TAC commitment and the OD group's amenability to ARC funding to promote the research. The application drew on OD's espoused commitments to storytelling and learning to challenge their defensiveness regarding evaluation. Once the industry signature was obtained, and the application successful, a potentially innovative and challenging project was created, legitimated by academia and the ARC, and supported by the industry participants on the TAC. However, lack of trust between the first author and the OD manager, and conflict between the OD group's unitarist philosophy and the academics' more pluralist-radical stance, were at least two factors that acted against the project's implementation. These 'failures' were not, however, evident at the outset. Moreover, the subsequent resignation of supportive members of the ISPP Board and TAC as well as senior champions within the University were not predicted. 
Secondly, during the 'Getting On' phase, the OD manager radically reduced the scope of the project, both in access to data and in forums for feedback and collaborative analysis. At the same time, however, the interviews did allow possibilities for exploring issues that OD were unable to monitor and control. Also, OD were unable to control informal contact between the academics and employees. In addition, and most importantly, the researchers and industry members of the TAC were heavily involved in another major change project in the plant. The researchers thus had alternative avenues through which to collect data on the OD program and provide feedback. This was far from the structured process envisioned in the original application but it had three elements that helped foster some effective collaboration. Firstly, diverse sources of data were collected for what was now a legitimate study of the OD program. Secondly, the truncated nature of the EFL project allowed the academics to spend more time on other, more effective, action research projects. Thirdly, the very circumstances and processes encountered during the EFL project provided useful data for an analysis of the politics of organizational research, particularly action research projects involving social constructivist methodologies. The current paper is such an outcome.

Thirdly, in the process of 'Getting Out', the OD manager could have had a major influence on the ability of the research team to publish and obtain future funding. This influence can, however, be exaggerated. Other sections of the collaborating company, more favorably disposed towards academic research, could be, and were mobilized to support further collaboration. Enthusiastic endorsement from a reluctant industry partner may not be necessary after all. Moreover, the effectiveness of control over publications varies widely, according to how much the university 
depends on the company, the mobility of researchers, turnover in industry personnel, and the degree to which industry partners read academic journals. Although publishing controversial material is risky, the scope for doing so is increased when long term links with companies are tenuous, personal ethics and basic anonymity requirements are addressed, when there are diverse interests and tensions within the collaborating company, when the industry partner him/herself would not wish to air his/her own betrayal of contractual obligations, and when there are professional arguments in favour of revealing 'behind the scenes' details.

\section{Conclusion}

Briefly, the project did not progress up the action research spiral in a trajectory specified in the ARC application. Although conditions for participatory action research in Australia seem beneficial, the EFL case study revealed a number of macro and micro conditions that not only undermined this particular project trajectory, but are arguably of wider relevance to critical action research in Australia and overseas. At the same time, however, there were a number of benefits from the project for both academia and industry. Did the weaknesses undermine the value of the project or did the achievements justify its execution? This is partly a political and subjective choice. However, we would like to make one appeal for the value of the project in providing material for analyzing some of the institutional problems that face critical action researchers. 
Despite a common awareness of the bricoleuring, non-rational nature of organizational life, including action research, many academics continue to impose an outdated rationalistic narrative on their own research endeavors. On the one hand, this may reveal something about the self-reflective capabilities of academics. While many are well-versed in documenting 'situational irony' in the actions of others (revealing the gap between espoused theories/human plans and aspirations on the one hand and theories in use/achievements and effects on the other), far fewer posses the 'ironic temper' necessary to understand (and even enjoy!) the existence of this phenomenon in their own life and work. On the other hand, there are conditions, as we have seen, that actively prevent such self-reflection and its communication. The concern of Australian universities with 'output' measures, means that if action research accesses industry funding, obtains competitive research grants and produces academic publications, then it is encouraged and supported. Yet, if these considerations clash with producing real reflective learning in organizations, ensuring that academic-industry relations really adhere to professional research ethics, or serious crafting of the development and use of academic research in a nonexploitative or dominating fashion, then academics raise such concerns at their peril. The formal policies and actions of ethics committees and funding bodies do little to challenge this inbuilt bias. Senior research administrators, academic funding bodies, and corporate alliances between universities and industry have processes and cultures that are far from sympathetic to those who place such concerns at the heart of their work. The purpose of this paper has been to reveal some of these problems and tensions in Australian action research. 
As Geertz (1968: 140) writes, 'As thought is conduct, the results of thought inevitably reflect the quality of the kind of human situation in which they were obtained.' Recognizing political pressures that threaten the 'results of thought' from critical action research, and the messy, contingent nature of attempts to cope with such pressures, may be an action researcher's version of what Geertz (1968) calls 'anthropological irony'. What Geertz is pointing us towards is the importance within academic fieldwork of the process itself - 'the journey is the thing': encouraging open and reflective communication between all parties on how academic ideas are put into practice, how they are compromised, the human dilemmas and professional ethics and identities involved and so on. This is no mere 'methodological' injunction but a key component of the 'output' of academic research and action - how researchers live out their ideals and conduct themselves in practice. An overly serious and misleadingly rationalistic understanding of action research, often supported (as we have seen here) by significant institutional pressures, betrays this promise. This paper has been written to help support what Anatole France is attributed to have said is the central characteristic of irony - "the gaiety of reflection and the joy of wisdom'. An ironic understanding of the inevitable gap between the idealistic political and cognitive aspirations and problematic mundane conditions of action research may help temper an inevitably pragmatic orientation with a simultaneously playful commitment to increasing mutual understanding of the messy, contradictory and all too human nature of the experience. In our terms, it can help make space for 'technologies of foolishness'. This paper seeks to contribute towards opening up this space by providing a brief, partial and yet hopefully illuminating account of fragility and uncertainty in an action research project that went awry. 


\section{References}

Argyris, C., 1982, Reasoning, Learning and Action: Individual and Oranizational, Jossey Bass, Englewood Cliffs

Badham, R., 2007 (forthcoming), 'Organizational Politics',In S.Clegg and J.Bailey (Eds.), International Encyclopedia of Organisational Studies, Sage, London

Badham and Sense, (2006), 'Spiralling Up or Spinning Out: A Guide for Reflecting on Action Research Practice, International Journal of Social Research methodology, Vol.9, No.5, pp.367-377

Badham, R., Dawson, P., Garrety, K., Griffiths, A., Morrigan, V. and Zanko, M. (2003), 'Designer Deviance: Enterprise and Deviance in Organizational Change', Organization Vol.10, No.4

Badham, R. and Selden, D., 1996, 'Industrialization of the University: Servant of Power or Critical Inquiry', Australian and New Zealand Academy of Management Conference, 12-15 December, Wollongong

Badham, R. \& Naschold, F., (1994), "New Technology Policy Concepts", in Aicholzer, G. \& Schienstock, G., (Eds.), Technology Policy: Towards an Integration of Social and Ecological Concerns, Berlin, De Gruyter 
Bell, D., (1947), 'Adjusting Men to Machines: Social Scientists Explore the World of the Factory', Commentary,

Baritz, L., (1960), Servants of Power, Wiley, New York

Buchanan, Boddy \& McCalman (1988), "Getting in, Getting on, Getting Out, Getting Back" in - Bryman, A. (Ed.) Doing Research in Organisations, Routledge, London

Cohen, M. D., March, J. G., and Olsen, J. P. (1972). A garbage can model of organizational choice. Administrative Science Quarterly, Vol.17, No.1, pp. 1-25.

Cohen, M.D. and March, J.G., (1974), Leadership and Ambiguity: The American College President, McGraw Hill, New Jersey

Dawson, P., (2003a), Understanding Organizational Change: the contemporary experience of people at work, Routledge, London

Dawson, P., (2003b), Reshaping Change: A Processual Perspective. Routledge, London

Dumont, J.-P., (1991), The Headman and I: Ambiguity and Ambivalence in the Fieldworking Experience, The Waveland Press, New York 
Dunphy, D.C. and Griffiths, A., (1998), The Sustainable Corporation: Organisational Renewal in Australia, Allen and Unwin, Melbourne

Einjatten, F. van, (1993), The Paradigm that Changed the Workplace, Stockholm, Arbetslivcentrum

Garrety, K. and Badham, R., (2000), The Politics of Sociotechnical Intervention: An Interactionist View, Technology Analysis and Strategic Management, Vol. 12, No.1, pp.103-119

Garrety, K, Badham, R. Morrigan, V., Rifkin, W. and Zanko, M., (2003), 'The Use of Personality Typing in Organizational Change: Discourse, Emotions \& the Reflexive Subject', Human Relations, Vol.56, No.2, pp.211- 235

Geertz , C., (1968), ‘Thinking as a Moral Act: Ethical Dimensions of Anthropological Fieldwork in the New States', Antioch Review, Vol.28, No.2, pp.139-158

Hampson, I., (1999), 'Between Control and Consensus: Globalization and Australia's Enigmatic Corporatism', in Edwards, P.K. and Elger, T. (Eds.), The Gobal Economy, Nation States and the Regulation of Labour, Routledge, London

Lincoln, Y..and Guba, E., ( 2005), Fourth Generation Evaluation, Sage, New York 
March, J. G. and J. P. Olsen (1983). "Organizing political life: what administrative reorganization tells us about government." American Political Science Review, Vol.77, No.2, pp. 281-96.

Mathews, J., (1994), Catching the Wave: Workplace Reform in Australia, Allen and Unwin, Melbourne

Quinn, J.B., (1980), Strategies for Change: Logical Incrementalism, Irwin, New York

Rose, N., (1999), Governing the Soul: The Shaping of the Private Self, Free Association Books, New York,

Turnbull, S., (2001), 'Quasi-Religious Experiences in a Corporate Change Programme - The Role sof Conversion and Confessional in Corporate Evangelism', Paper presented to Critical Management Studies Conference, Manschester, June Wotherspoon, R., (2002), Janus: An Ethnography of Engineering Design, Ph.D Thesis, University of Wollongong

Zanko, M., Badham, R., Couchman, P. and Schubert, M. (2007) (forthcoming), 'Innovation and HRM: Absences and Politics', International Journal of Human Resource Management. 


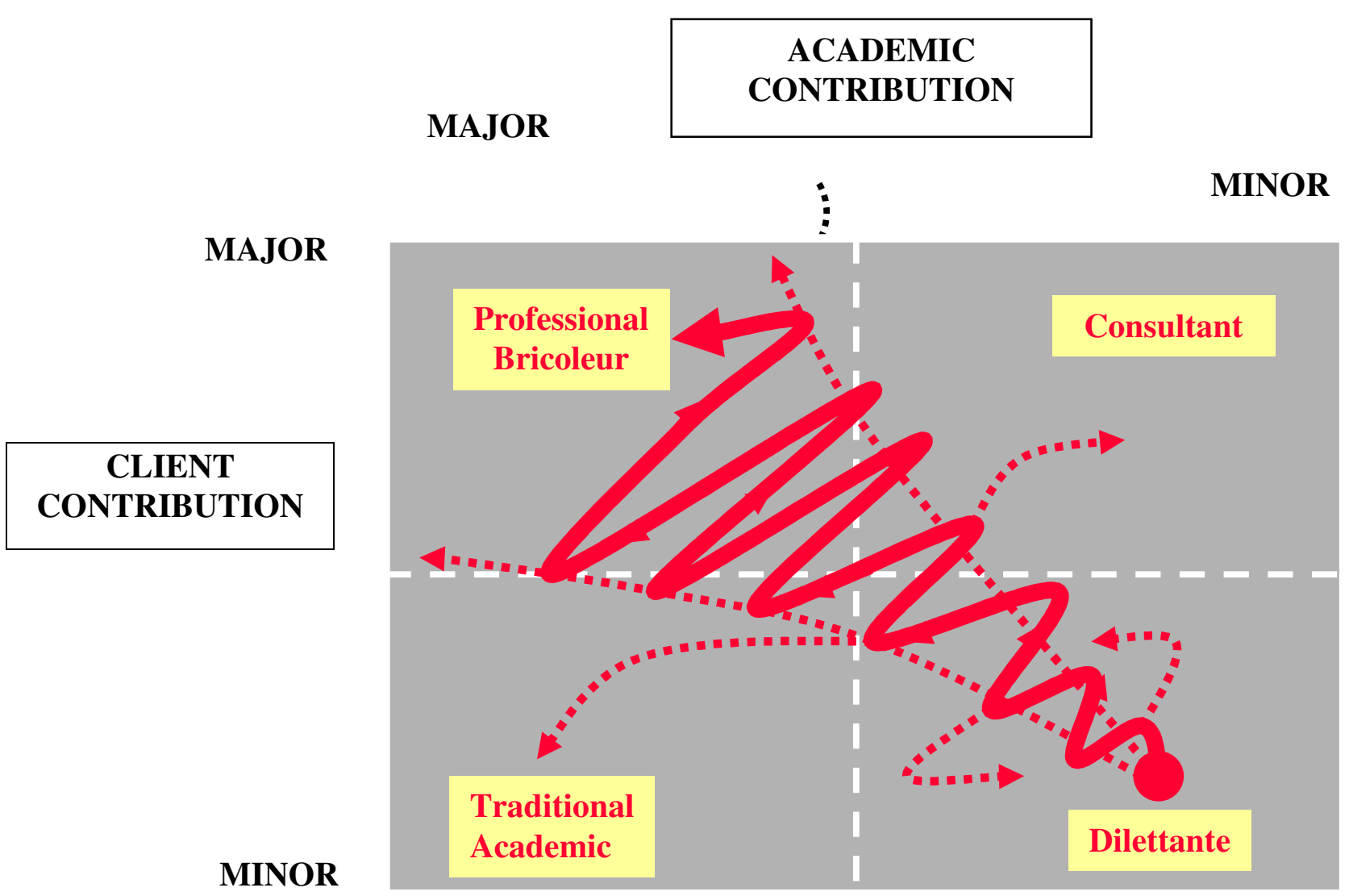

THE ACTION RESEARCH 'SPIRAL' 